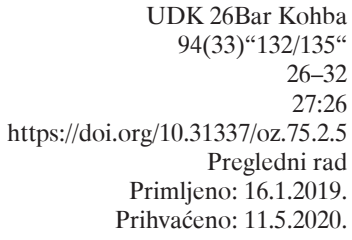

\title{
Aspekti razvoja židovske političke mesijanske misli nakon Bar Kohbina ustanka
}

Boris Havel*

\begin{abstract}
Sažetak
Iskustvo Drugoga židovskoga ustanka protiv Rimljana znatno je utjecalo na susljedni razvoj židovske misli u pitanjima mesijanizma i eshatologije. Mesijanizam je u srednjostrujaškom židovstvu postao pasivan, što se odrazilo na političke ambicije obnove židovske državnosti, koje su nakon 135. skoro potpuno splasnule. Posljedice ustanka zbog židovskoga su shvaćanja povijesti kao relevantne za teološku epistemologiju dovele do vjerski utemeljenoga političkoga kvijetizma, zbog kojega je vjerski židovski stav prema cionizmu sve do nedavno odražavao izrazitu nesklonost. Do promjene u tom stavu počelo je dolaziti iz istoga razloga, a to je povijesno iskustvo osnutka i obrane Države Izrael.
\end{abstract}

Ključne riječi: Bar Kohba; Judeja; Jeruzalem; Židovi; kršćani; mesija; mesijanizam; Palestina; cionizam; Izrael

\section{Uvod}

Bar Kohbin je ustanak potaknuo promjenu u židovskoj misli o mesijanizmu i mesiji, ${ }^{1}$ a mnoga su se srednjostrujaška židovska vjersko-politička stajališta oblikovala u njegovoj sjeni. Židovstvo se početkom 2. stoljeća nalazilo usred grčevita

Doc. dr. sc. Boris Havel, Fakultet političkih znanosti Sveučilišta u Zagrebu. Adresa: Lepušićeva 6, 10000 Zagreb, Hrvatska. ORCID iD: https://orcid.org/0000-0001-7809-9408. E-adresa: boris. havel@fpzg.hr

1 Koncept mesije u židovstvu nije statičan, nego se razumijevanje njegova značenja ili položaja mijenjalo kroz povijest. U Starom zavjetu Izraelovi su kraljevi i proroci bili pomazanici, što je značenje hebrejske riječi mašijah (משיח). Štoviše, Izaija $(45,1)$ perzijskoga kralja Kira naziva pomazanikom. Nakon kraja razdoblja Prvoga hrama pojam se mesije sve više počinje rabiti za opis osobe koja će obnoviti kraljevstvo u Izraelu, te uspostaviti vlast i "prijestolje zauvijek" (2 Sam 7,12-13). To je pretpostavka na temelju koje su i Isusovi učenici očekivali nastavak Isusove misije nakon uskrsnuća (Dj 1,6). Kasnije, u vrijeme Prvoga židovskoga ustanka protiv Rima 67.-73. godine mnogi su karizmatični ustanički vođe privukli sljedbenike izdajući se za pomazanike i obećavajući političko oslobođenje Erec Izraela uz božansku podršku (više o shvaćanju mesije u židovstvu do kraja razdoblja Drugoga hrama usp. McDonald i Porter, 2000, 63-65). U rabinskom židovstvu mesijanizam se je dalje razvijao, pa Scholem predlaže podjelu na "konzervativni," "restorativni" i "utopijski” (Scholem, 1971, 3). Različita shvaćanja koncepta mesije jedan je od razloga dvojbe 
napora da očuva identitet i preoblikuje formu bogoštovlja bez Hrama, donedavnoga središta sveukupnoga židovskoga života i vjere. Nakon ustanka, Židovi ne samo da su ostali bez političke vlasti, nego i bez domovine. Počeo je galut (גלות), veliko izgnanstvo koje je potrajalo skoro dva tisućljeća. Ustanak je duboko izmijenio politička i eshatološka očekivanja među Židovima na način da je mesijanska misao koja se nakon njega oblikovala poprimila gotovo isključivo duhovni, pasivistički i kvijetistički oblik, a aktivistički je, pobunjenički, ratnički državotvorni i suverenistički sadržaj — u obliku koji je obilježio puna tri stoljeća dotadašnje židovske povijesti, one između Makabejskoga i Bar Kohbina ustanka — iz nje iščeznuo. Aktivni mesijanizam, prožet vjerom kako Židovi kroz političku i vojnu uključenost u rješavanje pitanja nacionalne suverenosti mogu potaknuti ili ubrzati dolazak mesijanskoga doba i obnove Davidove kraljevine, u židovskoj je misli skoro postao oblik hereze. To je jedan od ključnih razloga zbog kojih je religijski židovski stav prema političkomu cionizmu desetljećima bio izrazito negativan. Obnova židovske državnosti s religijskoga je očišta, naime, poglavito vjersko, a ne političko pitanje, pa je većina rabina cionizam tumačila sa stajališta tradicije, a ne pragmatičnosti.

Znatan dio Židova obnovu je židovske državnosti još od vremena Drugoga hrama vidio kao djelo otkupljenja usko povezano s ostvarenjem mesijanskih obećanja. Mesijanska su očekivanja nakon Drugoga ustanka postala dijelom eshatoloških, a ne povijesnih nadanja Židova. Židovi su izgnanstvo iz Erec Izraela ${ }^{2}$ s vremenom počeli shvaćati kao pokoru, ${ }^{3}$ odnosno Božju kaznu koju valja strpljivo podnositi sve dok je Bog, svojom suverenom voljom, ne odluči privesti kraju. Naklapanja o vremenu Mesijina dolaska su zabranjena (Kedourie, 1988, 288), a započinjanje masovnoga, organiziranoga židovskoga povratka na Cion kako bi se obnovila državnost veći dio rabina smatrao je odrazom samovolje i prkosa prema Bogu. ${ }^{4}$

pisanja toga pojma velikim ili malim početnim slovom na hrvatskom jeziku, pa i u ovom članku. Veliko sam slovo stoga koristio ondje gdje je riječ o jednom, određenom mesiji.

2 Erec Izrael (ארץ ישראל) znači Zemlja Izraelova i odnosi se, ugrubo, na područja koja su kasnije, nakon Bar Kohbina ustanka, nazvana Palestinom. To je židovski, ali i biblijski — starozavjetni i novozavjetni naziv (usp. Mt 2,20) — za područje koje obuhvaća Judeju, Samariju, Galileju, a katkad i neke okolne pa i prekojordanske krajeve. Ime Palestina ne pojavljuje se ni u Starom ni u Novom zavjetu.

3 U Starom se zavjetu nalaze brojne prijetnje kako će Izrael biti izgnan iz svoje zemlje za kaznu zbog nepokornosti Božjemu Zakonu i Savezu (Lev 26,33; Pnz 4,27; 28,64-67, Neh 1,8; Ez 12,15; 20,23; Zah 7,14 i dr.). Nakon Ustanka Židovi su izgnanstvo shvaćali kao Božju kaznu, odnosno kao pokoru koja će ih na kraju dovesti do izmirenja s Bogom, Božjega opraštanja i njihova izbavljenja (גולה). To je proces "prekršaja, pokajanja i obnove« (Kedourie, 1988, 289) koji Židovi ne mogu samovoljno prekinuti, primjerice povratkom u Erec Izrael, nego moraju čekati da se Bog, nakon što se ispuni vrijeme pokore, smiluje i vrati ih iz progonstva kao što ih je nekoć vratio iz Babilona.

4 Odličan izvor za uvid u rabinske stavove u vrijeme ranoga cionizma djelo je Pioneers of Religious Zionism, u kojoj su opisani stavovi šestorice "alternativaca” među njima (Goldwater, 2009). 


\section{Palestinska Aelia Capitolina na ruševinama judejskoga Jeruzalema}

Rimljani su Bar Kohbin ustanak ugušili nakon tri godine teških borbi i gubitaka, zbog kojih se Hadrijan surovo osvetio buntovnomu židovskomu stanovništvu. Prvi put nakon Antioha Epifana židovstvo kao vjera se progoni (Klausner, 1955, 399). Premda Jeruzalem po svemu što nam je poznato nije bio poprište bitki, ${ }^{5}$ Hadrijanova je srdžba taj grad pogodila više i za Židove bolnije nego i jedan drugi. Hadrijan je sve židovsko stanovništvo protjerao iz Jeruzalema, u grad naselio tuđince, a ime grada promijenio u Aelia Capitolina. Jeruzalem je preimenovao po sebi, jer je njegovo puno ime bilo Publius Aelius Hadrianus, te po vrhovnom božanstvu rimskoga panteona Jupiteru Capitolinusu. Osim Jupiterova svetišta, na ruševinama židovskoga hrama Hadrijan je u Jeruzalemu izgradio još jedan poganski hram. Na mjestu koje su kršćani štovali kao mjesto Golgote i Kristova groba podignuto je svetište posvećeno Afroditi (Skarsaune, 2002, 53) 6 ili Veneri (Avi-Yonah, 2006, 31). ${ }^{7}$ Ako je Hadrijan te hramove gradio kako bi kaznio ustanike, može se pretpostaviti da su kršćanska i židovska zajednica u to vrijeme još uvijek bile bliske. To bi se kosilo s Justinovim i Euzebijevim izvješćem o sukobu kršćana, u tadašnjoj Judeji još uvijek većinski židovskoga podrijetla i identiteta, i Bar Kohbinih sljedbenika. No moguće je i da Rimljani naprosto nisu razlučivali kršćane od Židova, jer razlika između te dvije zajednice nije bila ni etnička ni religijska, nego interpretacijska: odnosila se na tumačenje Pisma i shvaćanje osobe Isusa iz Nazareta. ${ }^{8}$ I jedni i drugi bili su obrezani. Iznimka su bili nežidovski kršćani, čiji udio u judejskoj Crkvi nije poznat, ali je sasvim izvjesno da su činili manjinu (Skarsaune, 2002, 181). ${ }^{9}$ Židovi se u Jeruzalem, uz nekoliko kratkotrajnih iznimki, nisu smjeli vratiti punih pola tisućljeća, sve do muslimanskoga osvajanja grada 638. godine.

\subsection{Aelia kao rimski vojni logor}

Rimljani su Jeruzalem, sada Aeliju Capitolinu, sveli na vojni logor u koji se je smjestila rimska Deseta legija. Oko njega su djelomice podignuli nove zidine. Izvan tih zidina do danas je ostao izvorni Jeruzalem, Davidov grad, koji se nalazi u dolini na njihovoj južnoj strani. ${ }^{10}$ Oblik rimskoga logora, podignuta u Jeruzalemu nakon što je grad pretvoren u Aeliju Capitolinu, uvelike odgovara današnjemu obliku jeruzalemskoga Staroga grada (Kroyanker, 2002, 14; Kenyon,

$5 \quad$ Više o ustanku usp. Havel, 2019.

6 Na tom je mjestu u 4. stoljeću podignuta Crkva Svetoga groba.

7 Venera je u rimskom panteonu ekvivalent Afrodite u grčkom.

8 Danas unutar hasidskoga pokreta Habad postoje Židovi koji rabina Menachema Mendela Schneersona smatraju Mesijom, što ih ne čini manje ili više Židovima od onih koji to ne vjeruju, premda mnogi drugi Židovi tu njihovu vjeru oštro osuđuju i smatraju ju oblikom idolopoklonstva.

9 Opsežna studija o identitetima Židova i kršćana u prvim stoljećima kršćanstva nalazi se u zborniku radova Jewish Believers in Jesus (Skarsaune i Hvalvik, 2007).

10 Danas se ondje nalazi arapsko naselje Siluan. 
1964, 51-52), kako zidinama tako i glavnim ulicama koje prolaze kroz Stari grad. Rimljani su prema uobičajenoj arhitekturi kroz logor izgradili dvije glavne ulice koje se u središtu sijeku okomito. Jedna vodi od sjevernoga do južnoga ulaza u grad, a druga od istočnoga do zapadnoga ulaza. Damaščanska ili Šekemska vrata na sjeveru izgledno su bila glavni ulaz u Aeliju. Odmah iza njih, na visokom stupu postavljen je kip cara Hadrijana, koji je dominirao većim dijelom grada. Nasuprot Damaščanskim vratima, na južnom dijelu zida nalaze se Cionska vrata, tako nazvana jer se iza njih, izvan rimskih zidina, kao i onih koje su u 16. stoljeću izgradili Turci, nalazi gora Cion. Na zapadnom rubnom dijelu zida danas stoje Vrata Jafo, a na istočnom zidu, onom nasuprot Maslinskoj gori, Lavlja vrata i uz njih zazidana Zlatna vrata ili Vrata milosrđa. Otprilike u središtu jeruzalemskoga Staroga grada još uvijek je vidljiva središnja rimska osovina grada, koja se zove Cardo i u njoj dijelovi izvorne popločane ulice i potporni stupovi njezina natkrovlja.

\subsection{Ime Aelia do križarskih ratova}

Kršćani su prihvatili Hadrijanovu promjenu imena Jeruzalema, pa je latinsko ime Aelia ostalo u sporadičnoj uporabi u grčkom ili u izvornom latinskom obliku i nakon Konstantinova obraćenja i kanoniziranja knjiga Novoga zavjeta, premda su kršćani u "pisanim izvorima načelno grad nazivali 'Hierosalym' " (Lassner, 2006, 165). Islamski su osvajači tijekom prva tri stoljeća vladavine gradom Jeruzalem zvali Ilija. To je arapski oblik latinskoga Aelia, a ime pokazuje da je taj naziv bio dominantan u trenutku kad su muslimani grad 638. preoteli od Bizantskoga Carstva. ${ }^{11}$ Ime Aelia održalo se stoljećima, i tek je do vremena križarskih ratova skoro sasvim iščeznulo iz uporabe i u kršćanskoj i u muslimanskoj zajednici. Židovi ga nikad nisu prihvatili.

\subsection{Podrijetlo i uporaba imena Palestina}

Najdugotrajnija Hadrijanova promjena imena odnosi se na preimenovanje provincije Judeje u provinciju Siriju Palestinu. Ime Palestina dolazi od naziva kraljevine Filisteje, koja se je protezala uz obalu Sredozemnoga mora i obuhvaćala primorske gradove Gazu, Aškelon i Ašdod te Ekron i Gat u unutrašnjosti (Jš 13,3; 1 Sam 6,17). Judeja je, izgledno, preimenovana u Palestinu u isto vrijeme kad i Jeruzalem u Aeliju Capitolinu, »radi zatiranja njezina povijesnoga židovskoga identiteta « (Lewis, 1980, 2). Eshel opaža da »premda su se takve promjene imena događale i drugdje, nikada prije ni kasnije ime jednoga naroda nije izbrisano kao posljedica pobune« (Eshel, 2006, 127). Erec Izrael, dom židovskoga naroda tisuću i pol godina, tako je ostao bez imena, bez svetišta i bez naroda.

Judeja je u daljnju povijest ušla kao Palestina, a njezino se drevno ime s vremenom gotovo sasvim zagubilo. Glavni grad rimske pokrajine Palestine postala je Cezareja. Nakon Konstantinova obraćenja obnovljena je važnost Jeruzalema

11 Podrobnije o utjecaju imena Aelia na ranoislamsko ime grada usp. Havel, 2018, 134-138. 
i Palestine kao kolijevke kršćanstva, ali je ona velikim dijelom bila simbolična. I nakon islamskih osvajanja Palestina je ostala južna sirijska pokrajina, s Damaskom kao glavnim središtem toga širega područja. Početkom 8. stoljeća muslimani su izgradili Ramlu kao upravno središte pokrajine Palestine. Ime Palestina, za razliku od Aelije, s vremenom se sasvim uvriježilo u uporabi, pa čak djelomice i židovskoj. ${ }^{12}$

\section{Razvoj poslijeustaničkoga rabinskoga židovstva}

Rimljani su prognali "sve obrezane" ne samo iz Jeruzalema, nego i iz Judeje. Preživjeli su Židovi raspršeni po svijetu, a svojemu svetomu gradu više nisu smjeli prići. Time je Bar Kohbin ustanak Židovima nanio veću nacionalnu nesreću nego zauzimanje Jeruzalema i uništenje Hrama 70. godine. Da je Bar Kohbin ustanak prouzročio veće zlo nego i jedan drugi prethodni čin pobune vidljivo je iz kasnijih negativnih opisa Bar Kohbe u rabinskoj literaturi, premda u njima postoji i određena ambivalentnost. ${ }^{13}$ Uporaba naslova nasi (נשיא) u političkom je smislu prestala, a riječ se dalje javlja isključivo u vjerskom kontekstu, ${ }^{14}$ sve do razvoja modernoga hebrejskoga jezika, u kojem znači "predsjednik". ${ }^{15}$ Kasnije reakcije na Bar Kohbino proglašavanje mesijom, koje se poglavito povezuje s rabinom Akivom, kreću se od neodobravanja, koje nalazimo već u Jeruzalemskom Talmudu (JT Ta‘anit 24a), do čuđenja, uz napomenu kako je između 70. i 135. »politički čimbenik prevladavao u mesijanskoj ideji« (Klausner, 1955, 394-396). Nakon sloma ustanka, taj "politički čimbenik" iščezava. Židovi u Palestini više nikad nisu, potaknuti mesijanskim nadanjima, pokušali pokrenuti opći ustanak, pobunu ili sukob radi obnove vjerske i političke neovisnosti. Židovstvo postaje usredotočeno na proučavanje i tumačenje vjerskih tekstova, a političke ideje koje bi uključivale borbenost iz njega se potiskuju. Pitanje obnove Izraelove kraljevine postaje stvar Božje suverene intervencije, a povezivanje političkoga aktivizma s njom gotovo je svedeno na herezu. Praktična religija i praktična politika u židovstvu su se odvojile i za mnoga stoljeća ostat će odvojene.

Središte židovskoga vjerskoga, kulturnoga, obrazovnoga i nacionalnoga života nakon 135. postao je galut, u kojem je stoljećima živjela golema većina Žido-

12 Toponim Palestina sasvim se uvriježio u židovskoj znanosti (arheologija, historiografija), i tek se posljednjih desetljeća polako zamjenjuje terminom zemlja Izrael (ארץ ישראל). U vjerskim pak tekstovima Palestina nikad nije zaživjela.

13 Ambivalentnost ne treba prenaglašavati jer je židovska misao općenito nesklona oštrim interpretacijskim dihotomijama, a sklonija nijansiranosti. To je u znatnoj mjeri uvjetovano židovskim osjećajem za povijesnost, a povijesna zbivanja nisu crno-bijela. Primjer je židovska samokritičnost kakvu nalazimo u starozavjetnim knjigama (usp. Havel, 2013, 99-101).

14 Prva važnija osoba nakon Bar Kohbe koja je ponijela taj naslov bio je rabin Jehuda Ha-Nasi, glavni urednik Mišne.

15 Predsjednik Države Izrael je נשיא מדינת ישראל. 
va. ${ }^{16}$ Ta se promjena duboko odrazila na židovski identitet: Židovi su sve više iz etničke postali vjerska zajednica. ${ }^{17}$ Izraz "židovski kršćanin”, koji je označavao skupinu iz koje su dolazili Isusovi učenici, autori novozavjetnih knjiga i skoro svi prvi sljedbenici, prometnuo se je u oksimoron. Osim vjerskoga i političkoga, u židovstvu je došlo i do kulturološkoga preobražaja. Schürer ukazuje na to da je poraz Bar Kohbina pokreta donio i poraz helenizma među Židovima. Od vremena kad je Aleksandar Veliki zauzeo Judeju, a njezinim stanovnicima donio grčku misao, kulturu i svjetonazor, oni su katkad bržim a katkad sporijim tempom osvajali Židove i prodirali u židovstvo. Taj se proces nije zaustavio ni nakon makabejske pobjede nad Grcima i obnove židovske neovisnosti. Dapače, s učvršćivanjem vladavine Hasmonejaca helenizam je jačao, pa je u određenim trenutcima gotovo postojala opasnost da se židovstvo utopi u njemu. No nakon gubitka političke vlasti, Židovi su se usredotočili na ljubomorno čuvanje svojega jedinstvenoga vjerskoga identiteta, kao malo kad u prethodnih pola tisućljeća.

»Bez političkoga doma, objedinjeni samo oko ideala vlasti zajedničkoga zakona, Židovi su još ustrajnije nastavili prianjati uza svoje zajedničko prirođeno pravo i njegovati ga. Tako se sve oštrije određivala crta razdvajanja između njih i ostatka svijeta. U vrijeme procvata helenističkoga židovstva međa između židovskoga i grčko-rimskoga svjetonazora prijetila je iščeznućem, no Židovi i njihovi protivnici sada su zajedničkim snagama usmjerili pozornost na širenje toga jaza. Židovski helenizam, što je navješćivao bratstvo svih ljudi, nestao je, a farizejsko židovstvo, što je oštro odbacivalo svako zajedništvo s poganskim svijetom, steklo je opću prihvaćenost « (Schürer, 2009, 319).

Schürer opaža da su i pogani postali “nesnošljiviji” prema Židovima, jer više nisu kao do tad masovno u židovskom bogoštovlju tražili ispunjenje svojih duhovnih potreba. Obraćenika na židovstvo gotovo je nestalo. Važan je razlog bio taj što je mnoge među poganima koji su tražili Boga Izraelova privuklo kršćanstvo, a ono je, za razliku od židovstva, prozelitirajuća vjera.

Znatan dio raspršenih Židova u dijaspori s vremenom se je asimilirao. Neki su prihvatili kršćanstvo, a njihov se je židovski identitet nakon nekoliko naraštaja ugasio. Ostali su nastavili prianjati uza stare tradicije pridajući im tumačenja u skladu s novonastalim okolnostima. Do konca 3. stoljeća završena je kompilacija Mišne i Jeruzalemskoga Talmuda, a do konca 5. stoljeća Babilonskoga Talmuda. ${ }^{18}$ Uz rabinske spise, Židovi su koristili i Bibliju, što se do 19. stoljeća poglavito odnosilo na Toru (Shavit i Eran, 2007, 5). Žanr koji je u odnosu na predustaničko razdoblje znatno izgubio na važnosti mesijanska je i apokaliptična literatura o temi skoroga dolaska Mesije, koji će Izrael osloboditi od potlačenosti i obnoviti Davidovo kraljevstvo (McDonald, 2008, 174-175). Središte judaizma postala je

16 Godine 2018. službeno je objavljeno da je država u kojoj živi najveći broj Židova (6,6 milijuna) Izrael, a milijun manje živi ih u SAD-u. Nejasnoće u vezi s definiranjem nečije pripadnosti židovskomu narodu otežavaju ta statistička istraživanja (Rosenberg, 2018).

17 Usp. Goldenberg, 2006, 202-203, gdje autor objašnjava odnos između vjerskoga i etničkoga identiteta nakon uništenja Drugoga hrama.

18 Za više o nastanku i sadržaju tih tekstova usp. Da-Don, 2004, 512-520. 
Mezopotamija, gdje je pisan i prikupljan Babilonski Talmud. U rabinskoj misli koja je oblikovana u sljedećim stoljećima koncepti obnove izraelskoga kraljevstva, Jeruzalema i Hrama postali su usko povezani sa spremnošću na trpljenje, čežnjom, nadom i strpljivim iščekivanjem da Bog donese spasenje (geula), a »mesijanski se pasivizam razvio u jednu od okosnica rabinskoga judaizma « (Myers, 1991, 6).

\section{Preobrazba mesijansko-političke misli}

\subsection{Historična mesijanska misao}

Tumačenje razlike mesijanstva prije i mesijanstva poslije Bar Kohbina ustanka predstavio je James A. Sanders, koji objašnjava da je rabin Akiva vjerovao kako je Bar Kohba mesija, zbog kojega će Bog ustati protiv Rimljana i preko njega izbaviti svoj narod (Sanders, 2006, 235). ${ }^{19}$ Židovi su u to vrijeme mesijin dolazak smatrali Božjom intervencijom u svojoj povijesti, bez osobita utjecaja na ostatak svijeta — s iznimkom Rimljana koji će biti kažnjeni — i bez eshatoloških implikacija. U takvom mesijanizmu, koje se može nazvati historičnim, Mesijina je misija politička, pragmatična, nacionalna i izbaviteljska. Važna uloga u njezinu ostvarenju pripada židovskomu narodu, koji se ima djelatno uključiti u političke procese. On ne čeka da mu izbavljenje "padne s neba", nego se bori za njega, kao što se Izrael od izlaska iz Egipta borio, a Bog mu je, uvijek kad je narod bio vjeran Zakonu i Savezu, davao pobjedu.

Promjenu mesijanske misli donijelo je povijesno iskustvo. Povijest u židovstvu nije, niti je ikada bila, slijed zbivanja odvojenih od duhovne stvarnosti, nego ona ima epistemološku vrijednost za teologiju. Rabin Shubert Spero objašnjava: »Bog Izraelov Bog je povijesti; značenje i očitovanje Boga treba više tražiti u povijesnim zbivanjima i društvenim procesima nego u području prirode « (Spero, 1989, 41). ${ }^{20}$ Pogled na mesiju kroz prizmu povijesti sukladan je biblijskoj i poslijebiblijskoj židovskoj misli. Ako, naime, Bog djeluje u povijesti kroz narode, vladare, proroke, pa i obične, izvorno beznačajne pojedince izabrane iz mnoštva, poput Abrahama, Mojsija, Rute ili Davida, koliko više će oblikovati i usmjeravati povijest u korist Izraela preko Mesije kojega sam pošalje? Žar i čežnja s kojima su Židovi tijekom razdoblja Drugoga hrama očekivali da se Mesija pojavi među njima, kao jedan od njih, odražavali su duh toga vremena i židovstva u obliku u kojem se do tad razvilo. Taj je mesijanski žar nakon sloma Bar Kohbina ustan-

19 Po pitanju mesijanstva prije i poslije Bar Kohbe, Greenstone smatra da slom Bar Kohbina ustanka nije prouzročio zastoj u razvoju mesijanske nade jer učeni Židovi nisu dijelili vjeru u njegovo mesijanstvo (Greenstone, 1906, 91). Silver, pak, piše da je Bar Kohbin ustanak »raspršio mesijanske nade, a srca ispunio tragičnim razočaranjem, pa su rabini, što su živjeli nakon toga sudbonosnoga apokaliptičnoga poraza, mesijansku nadu nastojali predstaviti [kao događaj] daljnje budućnosti, kako bi time, ako je moguće, obeshrabrili ponovno raspirivanje intenzivne nade u Mesijin skori dolazak « (Silver, 1927, 15).

20 Rabin Haim David Halevi, na temelju takva shvaćanja povijesti, odredio je da je za Židova proučavanje povijesti micva (Katz, 2005, 280). 
ka ustupio mjesto drukčijemu, bitno opreznijemu viđenju Mesije i mesijanskoga doba. Ono se od tada sve manje povezuje s poviješću, a sve više s njezinim krajem.

\subsection{Eshatološka mesijanska misao}

Rabinsko židovstvo, Sanders objašnjava, oblikuje se u zajednici u kojoj Tora zacrtava misao i život. Židovi trebaju biti vjerni Tori sve dok Bog ne pošalje Mesiju u njegovo vrijeme »kao kraj povijesti i početak budućega svijeta, a ne kao intervenciju ili objavu u povijesti što je u tijeku « (Sanders, 2006, 236). Scholem piše da je mesijanizam, osobito onaj srednjovjekovni, halahički, usko povezan s apokaliptičnošću (Scholem, 1971, 4). Mesija će svojim dolaskom obaviti misiju koju su Židovi od njega očekivali i u stoljećima što su prethodila Bar Kohbinu ustanku, a to je obnova Davidove kraljevine, gradnja Hrama i ponovna uspostava obrednoga hramskoga bogoštovlja, ali ce istodobno donijeti neviđene nevolje, nemire, uskrsnuće mrtvih i konačni sud (Goldenberg, 2006, 202), što nije bio sadržaj ranijega mesijanizma srednjostrujaškoga židovstva. Taj je eshatološki mesijanizam oblikovao židovstvo u smislu da se mesiju više nije aktivno tražilo, pa čak ni odveć žarko iščekivalo, osim u vremenima koja su bila izrazito teška i u kojima je židovski narod trpio progone. Očekivanje Mesije ostalo je važan teorijski dio židovstva, ${ }^{21}$ ali mesije se u stvarnom životu više ne pojavljuju, osobito ne kao karizmatični predvodnici znatnijega broja oduševljenih sljedbenika. Iznimke, kao što je bio Šabtaj Cvi, teško se mogu usporediti s Bar Kohbom..$^{22}$ U razgovoru rabina krajem trećega stoljeća zabilježeno je da neki od njih uopće nisu željeli da Mesija dođe u njihovo vrijeme (BT Sanhedrin 98a-98b; usp. Goldenberg, 2006, 202). ${ }^{23}$

Očekivanje da će Mesijin dolazak sa sobom donijeti prevrate postojećih sustava vjerojatni je razlog kratkotrajne bizarne epizode kad su neki sirijski Židovi u kalifu Omaru ibn el-Hatabu nakratko prepoznali mesijansku figuru (usp. Crone i Cook, 1977, 5 i 154; Al-Tabari, 1992, 189). Rabin Martin L. Gordon predstavlja opis dvaju mesijanstava koji je sličan Sandersovu, premda koristi drukčija

21 O očekivanjima i izračunima dolaska mesijanskoga doba od 1. do 17. stoljeća, uključujući razlike u tim očekivanjima i izračunima prije i poslije Bar Kohbina ustanka, usp. Silver, 1927.

22 Židovski mesije nakon Bar Kohbe nisu imali osobita utjecaja na svekoliku židovsku zajednicu, što se samo djelomice može pripisati židovskoj raspršenosti. Među njima su vjerojatno najpoznatiji Šabtaj Cvi (1626.-1676.) i Menachem Mendel Schneerson (1902.-1994.). Više o poznatijim židovskim mesijama tijekom povijesti usp. Lenowitz, 1998. Za židovske vođe u mezopotamijskoj dijaspori (od vremena Babilonskoga sužanjstva do mongolskih osvajanja) koji se često oslovljavaju aramejski reiš galuta (ריש גלותֵ) vjerovalo se da su potjecali iz Davidova doma, pa su se stoga među Židovima Istoka kadgod smatrali mesijanskim ličnostima (usp. Gil, 2004). Oni su naslov nasljeđivali, a povremena mesijanska percepcija proizlazila je poglavito iz njihova podrijetla, a ne karizme.

23 Scholem zgodno veli da je židovski mesijanizam po svojoj prirodi "teorija katastrofe" (Scholem, 1971, 7), premda on u svojem eseju o mesijanizmu piše kao o fenomenu koji od biblijskih proroka do rabinskoga židovstva načelno slijedi idejni kontinuitet, s čime se autor ovoga teksta ne slaže. On ipak upozorava na to kako je došlo do promjene od proročke do apokaliptične ezoterične poruke o mesijanskim posljednjim vremenima, koja, usprkos brojnim pokušajima, još nije dovoljno jasno objašnjena (Scholem, 1971, 6-7). 
terminološka rješenja. On govori o jednom mesijanskom konceptu u kojem je naglasak na "ljudskoj drami” u kojoj nacionalni napor i inicijativa židovski narod usmjerava prema procesu otkupljenja i ostvarenju nacionalnoga cilja. Drugi mesijanizam predstavlja "božanski prevrat", stanje iznenadne apokalipse koja dovodi do neočekivane obnove Izraelovih pravednika i uništenja Izraelovih neprijatelja. U apokaliptičnoj viziji nema mjesta za poboljšanja unutar povijesnoga konteksta, pa ni za postupno poboljšanje političkih i duhovnih uvjeta u kojima Židovi žive. Prema njoj »odlučna nacionalna volja ne ce proizvesti nacionalnu neovisnost. Naprotiv, izvanredna natprirodna kataklizma nametnut će božansku vlast beznadnim zemaljskim okolnostima « (Gordon, 1989, 83). Slično kao Sanders, Gordon primjećuje da se tek nakon strašnoga poraza Bar Kohbina ustanka apokaliptična očekivanja utemeljena u očaju počinju u znatnoj mjeri pojavljivati u srednjostrujaškim tanaitičkim, a potom i amoraičkim izvorima. Članak završava zaključkom kako su zbivanja vezana za obnovu židovske državnosti pokazala da moderni religijski pokret mesijanizam ne smatra (samo) božanskim darom, nego »kolektivnom nacionalnom odgovornošću « (Gordon, 1989, 82-95).

Tijekom srednjega vijeka, normativno viđenje Mesije u srednjostrujaškom židovstvu postalo je ono koje je postavio Rambam u svojih trinaest načela židovske vjere. Dolazak Mesije predstavlja dvanaesto teološko načelo, a Da-Don objašnjava kako je mesijansko doba dio eshatološkoga, podijeljena u tri dijela: prvi su dani Mesije, drugi uskrsnuće mrtvih, a treći dolazak budućega svijeta. S Mesijinim dolaskom nastupit će vrijeme blagodati za židovski narod, nežidovski ce ih narodi prestati progoniti jer će se pokajati i shvatiti da je Izraelov Bog jedini pravi Bog. U tom viđenju mesijanskoga doba nema osobitih kataklizmičkih događaja, nego se Rambam poziva na riječi jednoga od talmudskih učenjaka: »Nema druge razlike između ovoga svijeta i mesijanskih dana, osim u robovanju kraljevstvima.«A tu leži Mesijina najvažnija zadaća: on će svekoliki židovski narod sa svih krajeva svijeta sabrati u Erec Izrael, izgradit će Treći hram, bit će vrhovni sudac svijeta te učitelj svim narodima o Bogu i Tori. Sva ta vjerovanja utemeljena su u Bibliji, a autor u tekstu navodi biblijske odlomke iz kojih su preuzeti. Promjenu mesijanske misli oslikava zaključna Da-Donova rečenica o toj temi: »Prema židovstvu, eshatološko će doba, mesijanski dani, nastupiti Božjom odlukom i određenjem, oviseći samo o njemu «(Da-Don, 2004, 664-669). I Rambamov je mesijanizam više "eshatološki" nego "povijesni”, ali se oni u nekim dijelovima preklapaju. U vrijeme emancipacije, pak, mesijanska su nadanja među europskim Židovima uvelike gubila privlačnost (Greenstone, 1906, 246).

Razvoj mesijanske misli i mijena iz "povijesnoga mesijanstva" u "eshatološko mesijanstvo" u židovskim se vjerskim tekstovima ne pripisuje iskustvu Bar Kohbina ustanka, nego se iz njih iščitava. Zato bi bilo teško ustvrditi da Bar Kohbin ustanak predstavlja točku oštra razgraničenja različitih teorija mesijanizma. On predstavlja prijelaz iz jednoga načelnoga shvaćanja mesijanizma u drugo, koje je s vremenom postalo normativno. Mesijanska je misao i prije i poslije bila višeslojna, složena, pokretna i evolutivna, pokatkad ambigvitetna. Ona je povezana i s drugim povijesnim procesima, koji su počeli davno prije Bar Kohbina ustanka, 
poput Babilonskoga sužanjstva, života bez političke vlasti u Judeji, helenizacije, Hasmonejskih previranja, razvoja rabinskoga židovstva, ishoda Prvoga ustanka, gubitka Hrama, jačanja dijaspore, pojave kršćanstva s alternativnom mesijanskom porukom i dr. Isusova poruka o "trudovima" (Mt 24,8) što će obilježiti njegov drugi dolazak odražava upravo ideju eshatološkoga mesijanstva. No opseg u kojem je židovstvo oblikovano nakon 135. godine postalo nesklono mesijanskoj ushićenosti pred povijesnim zbivanjima bez presedana je u prethodnim stoljećima. ${ }^{24} \mathrm{U}$ njemu se razvija nepovjerljivost prema karizmatičnom proroštvu i nespremnost da se zbivanja tumače kao božanske pozive na akciju. U tom se smislu Bar Kohbin ustanak može smatrati "prekretnicom" u oblikovanju mesijanizma kakav je postojao od početka razdoblja Drugoga hrama i mesijanizma koji je u židovskoj misli prevladavao tijekom sljedećih devetnaest stoljeća (Spero, 2000, 84).

\section{Država Izrael i reevaluacija mesijanizma}

Istom metodom kojom je mesijanstvo nakon 135. s vremenom svedeno na pasivno čekanje božanske eshatološke intervencije, zapaljena je iskra aktivističkoga mesijanizma. To je metoda tumačenja Božje volje kroz prizmu povijesnih zbivanja. Nastankom cionističkoga pokreta, a osobito nakon Izraelovih pobjeda 1948., te osobito 1967., otvorena je među Židovima polemika o tom nije li započelo mesijansko doba (Sanders, 2006, 236, bilj. 25) i trebaju li Židovi "požurivati otkupljenje", što je zagovarao preteča religijskoga cionizma rabin Alkalai (Goldwater, 2009, 21 i 25). Rabin Heschel piše kako je »stvaranje Države Izrael bilo poput čuda otvaranja Crvenoga mora « (Heschel, 1987, 203-204). ${ }^{25} \mathrm{U}$ židovskom vjerskom stavu prema naseljavanju Judeje i Samarije, koje je Izrael zauzeo 1967., razabire se jedan novi, cionistički mesijanizam, koji kao da zatvara dvotisućljetni krug i mesijanstvo vraća na oblike kakvi su postojali prije Bar Kohbe. Gordon u ranije navedenom eseju dva mesijanstva navodi kronologijom suprotnom od Sandersove: on u članku najprije govori o "apokaliptičnom" mesijanstvu, a tek potom o "povijesnom”, čemu je mogući razlog kontekst u kojem piše: njegov je članak objavljen u zborniku o religijskom cionizmu, pokretu u kojem se otkupljenje vidi kao proces u kojem važnu ulogu igra političko i vjersko djelovanje Židova, a ne kao iznenadna božanska intervencija i eshatološki potres uvjetovan isključivo metafizičkim procesima na koje čovjek ne može utjecati (Gordon, 1989, 82).

24 Valja imati na umu kako je mesijanski oprez postojao i prije. Klausner napominje da se Judu Makabejca nikad nije proglasilo mesijom, a »osoba mesije ne spominje se ni u jednoj knjizi pseudoepigrafe « (Klausner, 1955, 250). O rabinskom tumačenju i očekivanju mesijanskoga vremena prije i poslije Bar Kohbina ustanka usp. Silver, 1927, 14-27.

25 Heschelova je knjiga Israel: An Echo of Eternity općenito iznimno korisno štivo za razumijevanje uloge stvaranja Države Izrael u promjeni vjerskoga židovskoga stava prema političkom aktivizmu. Više o toj temi, uključujući iznimke u vidu nekih uglednih rabina koji su podržavali cionizam, te o promjenama koje su u vjerskoj zajednici nastale nakon 1967. usp. Havel, 2013, 381-488. O mesijanizmu koji je nakon Šestodnevnoga rata prožeo sekularnu zajednicu usp. Klein Halevi, 2013, xxii-xxiii. 


\section{Zaključak}

Židovski mesijanizam koji je postojao u vrijeme nastanka cionizma velikim se dijelom temeljio na povijesnom iskustvu Prvoga, a osobito Drugoga židovskoga ustanka. To je iskustvo pretočeno u tekstove rabinske književnosti, čime je stavljeno u teorijski okvir, ali to ne umanjuje činjenicu da je nastao iz povijesti, a ne iz teorije - iz iskustva, a ne iz objave. Ta se tvrdnja može zastupati metodom usporedbe mesijanizma nakon Bar Kohbina ustanka s mesijanizmom ili mesijanizmima koji su mu prethodili. Mesijanizam prije Bar Kohbe velikim je dijelom bio aktivan, angažiran, strastven, državotvoran i politički, a nacionalna židovska uključenost u povijesna previranja doživljavala se je kao relevantna za ostvarenje mesijanskih očekivanja. Mesijanizam nakon Bar Kohbe postao je eshatološki, apolitičan, pasivan i, skoro se može reći, prožet — Židovima inače nesvojstvenim — fatalizmom. Čežnja Židova za dolaskom mesijanskoga doba, otkupljenjem i obnovom Izraelove kraljevine nije nestala, ali se je njezino ispunjenje tijekom skoro dva tisućljeća nije tražilo kroz državotvorne pokrete, pobune, politički i društveni aktivizam, ni traženje mesijanskih ličnosti, nego kroz obdržavanje Zakona, molitvu, proučavanje Tore i čekanje da Bog privede kraju galut, a Izrael duhovno izbavi i politički obnovi. Bez razumijevanja povezanosti povijesnoga iskustva i preobrazbe mesijansko-političke misli teško je razumjeti suvremene političke procese u Izraelu, kroz koje politički aktivizam s mesijanskom konotacijom ponovno postaje prisutan u židovstvu. Židovstvo, pokazala je uspostava i obrana Države Izraela, nikad nije prestalo biti osjetljivo na teološke poruke povijesti, niti je prestalo biti spremno odazvati im se.

\section{Literatura}

Al-Tabari (1992). The History of al-Ṭabarī: Volume XII: The Battle of al-Qādisiyyah and the Conquest of Syria and Palestine. New York: State University of New York Press.

Avi-Yonah, Michael (2006). The Historical Background. U: Avi-Yonah, Michael; Amiran, David H.K.; Rothschild, Julius Jotham; Meyer, H.M.Z. (ur.). Jerusalem: The Saga of the Holy City. (str. 1-42). Delray Beach: Levenger Press.

Biblija. Jure Kaštelan i Bonaventura Duda (ur.), Biblija: Stari i Novi zavjet. Zagreb: Kršćanska sadašnjost, 1995.

BT Sanhedrin. U: Sefaria. URL: https://www.sefaria.org/Sanhedrin?lang=bi (26.9.2019.)

Crone, Patricia; Cook, Michael (1977). Hagarism: The Making of the Islamic World. Cambridge: Cambridge University Press.

Da-Don, Kotel (2004). Židovstvo: Život, teologija i filozofija. Zagreb: Profil.

Eshel, Hanan (2006). The Bar Kochba Revolt 132-135. U: Steven T. Katz (ur.), The Cambridge History of Judaism: Volume 4: The Late Roman-Rabbinic Period (str. 105-127). New York: Cambridge University Press.

Gil, Moshe (2004). Jews in Islamic Countries in the Middle Ages. Leiden: Brill.

Goldenberg, Robert (2006). The Destruction of the Jerusalem Temple: Its Meaning and Its Consequences. U: Steven T. Katz (ur.), The Cambridge History of Judaism: Volume 4: The Late Roman-Rabbinic Period (str. 191-205). New York: Cambridge University Press. 
Goldwater, Raymond (2009). Pioneers of Religious Zionism: Rabbis Alkalai, Kalischer, Mohliver, Reines, Kook and Maimon. Jerusalem: Urim Publications.

Gordon, Martin L. (1989). Messianism: Conflicting Conceptions. U: Shubert Spero i Yitzchak Pessin (ur.), Religious Zionism: After 40 Years of Statehood (str. 82-99). Jerusalem: Mesilot \& The World Zionist Organization.

Greenstone, Julius H. (1906). The Messiah Idea in Jewish History. Philadelphia: The Jewish Publication Society of America.

Havel, Boris (2013). Arapsko-izraelski sukob: Religija, politika i povijest Svete zemlje. Zagreb: Naklada Ljevak.

Havel, Boris (2018). Jerusalem in Early Islamic Tradition. Miscellanea Hadriatica et Mediterranea, 5(1), 113-179.

Havel, Boris (2019). Bar Kohba i Drugi židovski ustanak. Povijesni izvori: rimski, židovski, kršćanski i arheološki. Obnovljeni život, 74(4), 479-499.

Heschel, Abraham Joshua (1987). Israel: An Echo of Eternity. New York: Ferrar, Straus and Giroux.

JT Ta'anit. U: Sefaria. URL: https://www.sefaria.org/Jerusalem_Talmud_Ta'anit?lang=bi (26.9.2019.)

Katz, Steven T. (2005). The Impact of the Holocaust on Jewish Theology. New York: New York University Press.

Kedourie, Elie (1988). Judaism and Zionism in the Holy Land. U: Moshe Sharon (ur.), Pillars of Smoke and Fire: The Holy Land in History and Thought (str. 287-291). Johannesburg: Southern Book Publishers.

Kenyon, Kathleen M. (1964). Excavations in Jerusalem 1961-1963. The Biblical Archaeologist, 27(2), 33-52.

Klausner, Joseph (1955). The Messianic Idea in Israel: From Its Beginning to the Completion of the Mishna. New York: The Macmillan Company.

Klein Halevi, Yossi (2013). Like Dreamers: The Story of the Israeli Paratroopers Who Reunited Jerusalem and Divided a Nation. New York: Harper Collins Publishers.

Kroyanker, David (2002). Jerusalem Architecture. Jerusalem: The Vendome Press.

Lassner, Jacob (2006). Muslims on the sanctity of Jerusalem: Preliminary thoughts on the search for a conceptual framework. Jerusalem Studies in Arabic and Islam, 31, 164-195.

Lenowitz, Harris (1998). The Jewish Messiahs: From the Galilee to Crown Heights. New York: Oxford University Press.

Lewis, Bernard (1980). Palestine: On the history and geography of a name. The International History Review, 2(1), 1-12.

McDonald, Lee Martin (2008). The Biblical Canon: Its Origin, Transmission, and Authority. Peabody: Hendrickson Publishers.

McDonald, Lee Martin; Porter, Stanley E. (2000). Early Christianity and its Sacred Literature. Peabody: Hendrickson Publishers.

Myers, Jody Elisabeth (1991). The Messianic Idea and Zionist Ideologies. U: Frankel, Jonathan (ur.). Jews and Messianism in the Modern Era: Metaphor and Meaning (str. 3-13). New York: Oxford University Press.

Rosenberg, David (2018). Minister: It's official - More Jews in Israel than US. Arutz Sheva 7: Israel National News. URL: http://www.israelnationalnews.com/News/News. aspx/248357 (19.10.2019.)

Sanders, James A. (2006). The Canonical Process. U: Steven T. Katz (ur.), The Cambridge History of Judaism: Volume 4: The Late Roman-Rabbinic Period (str. 230-243). New York: Cambridge University Press. 
Scholem, Gershom Gerhard (1971). The Messianic Idea in Judaism and Other Essays on Jewish Spirituality. New York: Schocken Books.

Schürer, Emil (2009). A History of the Jewish People in the Time of Jesus Christ: First Division: Volume II: Political History of Palestine: From B. C. 175 to A. D. 135. Peabody: Hendrickson Publishers.

Shavit, Yaacov; Eran, Mordechai (2007). The Hebrew Bible Reborn: From Holy Scripture to the Book of Books: A History of Biblical Culture and the Battles over the Bible in Modern Judaism. Berlin: Walter de Gruyter.

Silver, Abba Hillel (1927). A History of Messianic Speculation in Israel: From the First through the Seventeenth Centuries. New York: The Macmillan Company.

Skarsaune, Oskar (2002). In the Shadow of the Temple: Jewish Influence on Early Christianity. Downers Grove: InterVarsity Press.

Skarsaune, Oskar; Hvalvik, Reidar (ur.) (2007). Jewish Believers in Jesus: The Early Centuries. Peabody: Hendrickson Publishers.

Spero, Shubert (1989). The Religious Meaning of the State of Israel. U: Spero, Shubert; Pessin, Yitzchak (ur.). Religious Zionism: After 40 Years of Statehood (str. 40-58). Jerusalem: Mesilot \& The World Zionist Organization.

Spero, Shubert (2000). Holocaust and Return to Zion: A Study in Jewish Philosophy of History. Hoboken: Ktav Publishing House.

Aspects of Development of Jewish Political Messianic Idea after the Bar Kokhba Revolt

Boris Havel*

\section{Summary}

The second Jewish revolt against the Romans has significantly influenced the shaping of subsequent Jewish messianic and eschatological thought. Largely due to the Revolt, mainstream Judaism has adopted a passive messianic attitude, and Jewish ambitions to reestablish statehood in Palestine has almost entirely subsided. Historical experience of the Bar-Kokhba revolt combined with the Jewish perception of history, as relevant to theological epistemology, has produced faith-based political quietism which marked Judaism for centuries. The attitude of religious Jews to political Zionism, when it first appeared, was very averse and remained such until rather recently. Change in the attitude was prompted by the same reason, which is historical experience of the establishment and defense of the State of Israel.

Key words: Bar Kokhba; Judaea; Jerusalem; Jews; Christians; Messiah; Messianism; Palestine; Zionism; Israel

* Boris Havel, Ph.D., Assistant Professor, Faculty of Political Sciences, University of Zagreb. Address: Lepušićeva 6, 10000 Zagreb, Croatia. E-mail: boris.havel@fpzg.hr 